\title{
Identification and characterization of insulin-like growth factor (IGF)-binding protein expression and secretion by adult human adrenocortical cells: differential regulation by IGFs and adrenocorticotropin
}

\author{
C Fottner, D Engelhardt ${ }^{1}, M$ Elmlinger $^{2}$ and $M M$ Weber \\ Medical Department II, University of Cologne, Cologne, Germany \\ ${ }^{1}$ Medical Department II, Klinikum Grosshadern, University of Munich, Munich, Germany \\ ${ }^{2}$ Children's Hosital, Pediatric Endocrinology, University of Tübingen, Tübingen, Germany \\ (Requests for offprints should be addressed to M M Weber, Lehrstuhl II für Innere Medizin der Universität zu Köln, Medizinische Univesitätsklinik \\ Köln-Merheim, Ostmerheimerstraße 200, 51109 Köln, Germany)
}

\begin{abstract}
In previous studies we have shown that IGF-II stimulates basal as well as ACTH-induced cortisol secretion from adult human adrenocortical cells more potently than IGF-I, and that both IGFs predominantly stimulate androgen biosynthesis. The steroidogenic effect of IGF-I and IGF-II is mediated through interaction with the IGF-I receptor, and modified by locally produced IGF-binding proteins (IGFBPs). In the present study, we identified and characterized IGFBP synthesis in normal adult human adrenocortical cells in primary culture, and investigated the effect of ACTH and recombinant human IGF-I and -II on the regulation of IGFBP expression and secretion.

Using RT-PCR, we identified the mRNA of all six high-affinity IGFBPs, in both adrenocortical tissue and monolayer cell cultures of adrenocortical cells. Using Western ligand and immunoblotting and two-dimensional Western ligand blotting we confirmed the secretion of IGFBP-1, -2, -3, -4 and -5 by adrenocortical cells in primary culture.

The quantification of IGFBPs indicated that IGFBP-3 accounts for almost half the binding activity in conditioned medium of unstimulated cells (47\%), followed by
\end{abstract}

IGFBP-4 (20\%), IGFBP-5 (15\%), IGFBP-2 (12\%) and IGFBP-1 (6\%). After treatment with ACTH, the abundance of IGFBP- 1 was upregulated significantly $2 \cdot 6$-fold, while IGFBP-3 was induced only slightly $(1 \cdot 3$-fold). IGFBP-2, -4 and -5 remained unchanged. In contrast, IGF-I and -II $(6.5 \mathrm{nM})$ predominantly induced the abundance of IGFBP-5 (2- and 1.6-fold respectively) and IGFBP-3 (2- and 1.7-fold respectively), while IGFBP-1, -2 and -4 were unaltered. The induction of IGFBP-1 and -5 by ACTH and IGFs, respectively, was paralleled by an increase in the amount of IGFBP-1 and -5 mRNA in these cells.

In conclusion, all six high-affinity IGFBPs are expressed in the adult human adrenal gland, and the presence of at least five high-affinity IGFBPs has been demonstrated in conditioned medium of adult human adrenocortical cells. Furthermore, the expression and secretion of IGFBP-1 is upregulated by ACTH, whereas IGFBP-5 is induced by IGF-I and -II. Together with earlier findings, these results suggest that IGFBPs play an important modulatory role in the regulation of the differentiated adrenocortical function. Journal of Endocrinology (2001) 168, 465-474

\section{Introduction}

The insulin-like growth factors (IGF-I and IGF-II) are polypeptides, structurally related to proinsulin, which have been implicated in the hormonal regulation of growth and differentiation. IGF-I mediates the growth-promoting effects of growth hormone in postnatal life, while IGF-II seems to be involved in the regulation of fetal growth. IGFs show mitogenic and differentiation-promoting activities in a variety of tissues, where they are produced locally and presumably act in a paracrine/autocrine manner
(Underwood et al. 1986, LeRoith et al. 1991). Both ligands interact with specific cell surface receptors to which they bind with differing affinities. While most of the effects of IGF-I and IGF-II are mediated through interaction of the ligands with the type I IGF receptor, the role of the type II IGF receptor in IGF signaling remains controversial (Roth 1988, Rechler \& Nissley 1990). Furthermore, IGFs bind to a variety of IGF-binding proteins (IGFBPs) which are present in many tissues and body fluids and take part in the regulation of IGF action (Clemmons 1990, Jones \& Clemmons 1995, Rechler 1995). 
There are accumulating data that IGFs play an important role in the regulation of growth and differentiation of the adrenal gland. Adult human adrenocortical glands express IGF-I, to a lesser extent IGF-II, and both types of the IGF receptor (Weber et al. 1997). Furthermore, IGFs elicit mitogenic as well as differentiating effects in adrenocortical cells in vitro (Pham-Huu-Trung et al. 1991, L'Allemand et al. 1996, Kristiansen et al. 1997), and an overexpression of IGF-I receptors, IGF-II and IGFBP-2 has been described in adrenocortical carcinomas (Voutilainen \& Miller 1987, Ilvesmäki et al. 1993, Gicquel et al. 1994, Boulle et al. 1998). Previously, we have shown that IGF-II - through interaction with the IGF-I receptor - stimulates basal as well as adrenocorticotropin (ACTH)induced steroid secretion from adult human and bovine adrenocortical cells more potently than IGF-I, and that the different potency of IGF-I and IGF-II is presumably due to an interaction of the ligands with locally produced IGFBPs (Weber et al. 1995, Fottner et al. 1998). In order to further evaluate the role of IGFBPs in the adult human adrenal gland, the IGFBPs secreted by adult human adrenocortical cells were identified, characterized, and their expression was confirmed by RT-PCR. Furthermore, the regulation of their secretion and expression by ACTH and IGFs was assessed.

\section{Materials and Methods}

\section{Materials}

Recombinant human IGF-I and IGF-II were purchased from Boehringer Mannheim (Mannheim, Germany), $\mathrm{ACTH}^{1-24}$ (Synacthen) was purchased from Ciba-Geigy (Basel, Switzerland). 3-[ $\left.{ }^{125} \mathrm{I}\right]$ Iodotyrosyl-labeled IGF-I and IGF-II (human recombinant, specific activity $2000 \mathrm{Ci} / \mathrm{mmol}$ ) were purchased from Amersham Buchler (Braunschweig, Germany). Molecular biology reagents for RT-PCR were purchased from Promega (San Diego, CA, USA) and Gibco BRL (Eggenheim, Germany). Polyclonal rabbit antiserum against human IGFBP-1 was a kind gift from Dr Hans Bohn (Behringwerke, Marburg, Germany), another polyclonal antibody against human IGFBP-1 was purchased from DSL (Webster, TX, USA). Polyclonal antibody against human IGFBP-2 was developed by M W E and polyclonal antibody against human IGFBP-4 and IGFBP-6 was purchased from Austral Biological (San Ramon, CA, USA). Polyclonal antibody against human IGFBP-3 was from DSL, and polyclonal anti-human IGFBP-5 was purchased from Upstate Biotechnology (Lake Placid, NY, USA).

\section{Tissue preparation and cell culture conditions}

Tissue from normal adult human adrenal glands was obtained from patients who underwent total unilateral nephrectomy due to renal carcinoma in accordance with the guidelines of the local ethical committee. Immediately after surgical removal, the tissue was dissected by the pathologist and a sample of fresh non-necrotic adrenal tissue was provided. All adrenal glands were found to be normal after morphological and histopathological examination. For mRNA extraction from intact adrenal glands, adrenal glands were freed from the periadrenal fat tissue, incised longitudinally and the adrenal medulla was separated from the cortex under a dissecting miscroscope.

Monolayer cell cultures of adult human adrenocortical cells were prepared as described previously (Weber et al. 1998). In brief, adrenocortical tissue was separated, enzymatically dispersed with $1 \%$ collagenase II and $0 \cdot 25 \%$ desoxyribonuclease I $\left(30 \mathrm{~min}\right.$ at $\left.37^{\circ} \mathrm{C}\right)$, filtered $(100 \mu \mathrm{m})$ and centrifuged $(5 \mathrm{~min}$ at $400 \mathrm{~g}$ ). Red blood cells and cell debris were removed by washing with phosphatebuffered saline (PBS) followed by Percoll centrifugation $\left(r=1.07 \mathrm{~g} / \mathrm{ml}, 37^{\circ} \mathrm{C}\right.$; Pharmacia, Uppsala, Sweden $)$ for $10 \mathrm{~min}$ at $730 \mathrm{~g}$. The band containing adrenocortical cells was washed twice with PBS, and resuspended in cell culture medium M199 (Gibco BRL) containing 10\% fetal calf serum, $5 \%$ horse serum, L-glutamine $(290 \mu \mathrm{g} / \mathrm{ml})$, gentamycin $(50 \mathrm{mg} / \mathrm{ml})$ and amphotericin B $(0.5 \mathrm{mg} /$ $\mathrm{ml})$ ). Adrenocortical cells were then grown in monolayers at $37^{\circ} \mathrm{C}$ in a humidified atmosphere with $95 \%$ air- $-5 \%$ $\mathrm{CO}_{2}$ for 3-4 days in $22 \mathrm{~mm}$ multiwell plates. Twenty-four hours prior to the experiments the medium was exchanged to serum-free medium (M199 containing L-glutamine $(290 \mu \mathrm{g} / \mathrm{ml})$, gentamycin $(50 \mathrm{mg} / \mathrm{ml})$ and amphotericin B $(0.5 \mathrm{mg} / \mathrm{ml}))$. Treatment of the cell culture with ACTH under serum-free conditions induced a dose-dependent increase in cortisol secretion with a half-maximal stimulation at $1 \mathrm{nM}$ ACTH. At confluency, cell density was $3-5 \times 10^{5}$ cells/well and cell viability was $>95 \%$ as confirmed by trypan blue exclusion after $96 \mathrm{~h}$ of incubation.

\section{Experimental procedure and stimulation experiments}

Adult human adrenocortical cells $\left(3-5 \times 10^{5}\right.$ cells/well $)$ were incubated with $1 \mathrm{ml}$ serum-free medium with or without ACTH (1 nM) and IGFs $(6.5 \mathrm{nM})$ for up to $72 \mathrm{~h}$. At the end of the experiments, medium was aspirated, a mixture of protease inhibitors (Complete; Boehringer Mannheim) was added and conditioned cell culture medium was concentrated tenfold for Western ligand blot (WLB) analysis in a Millipore ultrafree filter unit (Millipore, Munich, Germany). Samples were stored at $-30{ }^{\circ} \mathrm{C}$ for further analysis. Cells from monolayer cell culture were harvested, pooled for treatment groups, and stored in liquid nitrogen for subsequent mRNA extraction.

\section{RNA isolation}

For RNA extraction, $50 \mathrm{mg}$ adrenocortical tissue or $10^{6}$ cells were incubated with $1 \mathrm{ml}$ cell lysis buffer for $5 \mathrm{~min}$, 
then total RNA was isolated using the acid guanidiniumisothiocyanate-phenol chloroform extraction method described by Chomczynski \& Sacchi (1987). The concentration and purity of the RNA were determined by ultraviolet spectrophotometry. RNA was frozen at $-70{ }^{\circ} \mathrm{C}$ until analyzed.

\section{RT-PCR}

After RNA extraction, PCR analysis was performed as described previously (Elmlinger et al. 1998). In brief, for the generation of cDNA, $1.0 \mu \mathrm{g}$ total RNA template was incubated for $60 \mathrm{~min}$ at $37^{\circ} \mathrm{C}$ in $20 \mu \mathrm{l}$ reaction volume, containing $5 \times 1$ st strand buffer $(50 \mathrm{mM}$ Tris $-\mathrm{HCl}$, $75 \mathrm{mM} \mathrm{KCl}$ ), $3 \mathrm{mM} \mathrm{MgCl} 2,0.5 \mathrm{mmol} / 1$ of each deoxynucleotide, $2.5 \mu \mathrm{mol} / 1$ oligo $\mathrm{d}(\mathrm{T})$ primer, dithiothreitol $(10 \mathrm{mM}), 24 \mathrm{U}$ ribonuclease inhibitor RNasin $(1 \cdot 2 \mathrm{U} / \mu \mathrm{l})$ and $400 \mathrm{U}$ murine Maloney monkey leukemia virus reverse transcriptase $(\mathrm{RT} ; 20 \mathrm{U} / \mu \mathrm{l})$. The reaction was stopped by incubation at $95{ }^{\circ} \mathrm{C}$ for $5 \mathrm{~min}$ and samples were placed on ice or stored at $-20^{\circ} \mathrm{C}$ for further analysis. For cDNA amplification, $2 \mu \mathrm{l} \mathrm{RT}$ product was amplified in a volume of $50 \mu \mathrm{l}$, containing $10 \times \mathrm{PCR}$ buffer $(10 \mathrm{mM}$ Tris- $\mathrm{HCl}, \mathrm{pH} 8 \cdot 4,50 \mathrm{mM} \mathrm{KCl}), 1 \cdot 0$ $2 \cdot 0 \mathrm{mM} \mathrm{MgCl}, 200 \mu \mathrm{M}$ of each deoxynucleotide, $0 \cdot 4 \mu \mathrm{M}$ of each primer and $0.06 \mathrm{U} / \mu \mathrm{l}$ Taq DNA polymerase. PCR procedures, i.e. annealing temperature, time and $\mathrm{MgCl}_{2}$ concentrations, were optimized for each primer pair. For amplification of the DNA fragments, a cycle number which was in the middle of the linear amplification range (with a minimum of 24 and a maximum of 29 cycles) was used. Criteria for primer choice were the following: with regard to the protein structure of the aligned IGFBP-1 to -6 sequences, we chose primers (with no intra- and intermolecular homologies) in reference to the middle domain of the mature IGFBP-1 to -6 , where minimum homology is found between IGFBPs (Rechler 1993). A 131 base pair (bp) fragment of IGFBP-1 corresponding to nucleotides 425-446 and 555-534 of the human IGFBP-1 cDNA sequence was amplified using the following primers, sense: 5'GAGAGCACGGGAGATA ACTGAGG3', antisense: 5'TTGGTGACATGGAGAG CCTTCG3'. A $170 \mathrm{bp}$ fragment of IGFBP-2 corresponding to nucleotides 572-593 and 741-724 of the human IGFBP-2 cDNA sequence was amplified using the following primers, sense: 5'ATGGCGATGACCACTCAG AAGG3', antisense: 5'ACCCTTGCCCATCTGCCG3'. A $175 \mathrm{bp}$ fragment of IGFBP-3 corresponding to nucleotides 5915-5933 and 8227-8212 of the human IGFBP-3 cDNA was amplified using the following primers, sense: 5'AGAACTTCTCCTCCCAGTC3', antisense: 5'CTT TGGAAGGGCGACACTG3'. A $435 \mathrm{bp}$ fragment of IGFBP-4 corresponding to nucleotides 399-416 and 851834 of the human IGFBP-4 cDNA sequence was amplified using the following primers, sense: 5'ATCGAGG CCATCCAGGAA3', antisense: 5'AAAGCTGTCAGC
CAGCTG3'. A 170 bp fragment of IGFBP-5 corresponding to nucleotides $385-406$ and 554-533 of the human IGFBP-5 cDNA was amplified using the following primers, sense: 5'TCAAGATCGAGAGAGACTC CCG3', antisense: 5'GACAAACTTGGACTGGGTC AGC3'. A $525 \mathrm{bp}$ fragment of IGFBP-6 corresponding to nucleotides 175-194 and 699-673 of the human IGFBP-6 cDNA was amplified using the following primers, sense: 5'AAGCTGAGGGCTGTCTCAGG3', antisense: 5'AGG AGCAGCTTCCATTGCCATCTGGAG3'. A 357 base pair bp fragment of glyceraldehyde-3-phosphate dehydrogenase (GAPDH) corresponding to nucleotides 252-1272 and 609-590 of the human GAPDH cDNA sequence was amplified using the following primers, sense: $5^{\prime}$ CGGG AAGCTTGTGATCAATGG3', antisense: 5'GGCAGT GATGGCATGGACTG3'. Semiquantitative PCR was performed using a GAPDH expression of each sample, which served as an internal control of mRNA expression as described previously (Elmlinger et al. 1996). After acrylamide electrophoresis, the PCR products for the specific IGFBP and GAPDH were stained with ethidium bromide. Quantification was performed by scanning the specific bands and comparing the corresponding areas under the curves with a specific software package (WinCam 2·1; Cybertech, Berlin, Germany). Results are expressed as relative levels of specific mRNA normalized for GAPDH.

\section{Western ligand blotting}

IGFBPs were characterized in the conditioned medium from stimulation experiments by WLB as previously described (Weber et al. 1995). In brief, $1 \mathrm{ml}$ medium was concentrated tenfold in a Millipore ultrafree filter unit and $50 \mu \mathrm{l}$ sample was separated by $12 \%$ SDS-PAGE under non-reducing conditions in a Laemmli buffer system. Proteins were electrotransblotted onto polyvinylidentiflouride (PVDF) membranes (Imobilon; Millipore). The IGFBPs were identified by autoradiography following overnight incubation of the filters with ${ }^{125}$ I-labeled IGF-I or IGF-II at $4{ }^{\circ} \mathrm{C}$. Quantitative evaluation of ligand blots was carried out according to the method of Zapf et al. (1990) by cutting marked bands from the PVDF membrane and assessing their activity by gamma counting. In order to correctly localize even closely migrating bands with different activities, at least two autoradiographic films with different exposure times were performed for each gel before cutting the bands from the gel. For deglycosylation of IGFBPs, the conditioned medium was concentrated tenfold and incubated with $3 \mu \mathrm{l}$ endoglycosidase $\mathrm{F} / \mathrm{N}$-glycosidase $\mathrm{F}$ (Boehringer Mannheim) for $3 \mathrm{~h}$ at $37^{\circ} \mathrm{C}$ prior to WLB.

\section{Immunoprecipitation of IGFBPS}

Protein A (20 mg; Pharmacia) was washed twice with PBS and centrifuged. Specific IGFBP antiserum $(10 \mathrm{ml})$ was 
added to the washed Protein A and preincubated for $1 \mathrm{~h}$ at room temperature. Conditioned cell culture medium $(2 \mathrm{ml})$ containing $50 \mu \mathrm{l}$ of a mixture of protease inhibitors (Complete) was added to the washed Protein A and incubated at $4{ }^{\circ} \mathrm{C}$ overnight. Samples were then centrifuged at $300 \mathrm{~g}$ and washed twice with PBS. The pellet containing immunoprecipitated IGFBPs was resuspended in $50 \mu \mathrm{l}$ sample buffer and boiled for $5 \mathrm{~min}$. After centrifugation at $300 \mathrm{~g}$, the supernatant was aspirated and subjected to WLB analysis as described (Weber et al. 1995).

\section{Western immunoblotting}

Samples were subjected to non-reducing gel electrophoresis and electrotransferred to PVDF membrane as described above. The membrane was blocked with $5 \%$ bovine serum albumin (BSA) and $0 \cdot 1 \%$ Tween 20 in PBS for $12 \mathrm{~h}$ prior to incubation with the indicated IGFBP antiserum in PBS containing 1\% BSA and $0 \cdot 1 \%$ Tween 20 for $3 \mathrm{~h}$. The PVDF membranes were washed twice with PBS containing $0 \cdot 1 \%$ Tween 20 and incubated with a peroxidaselabeled second antibody for another $2 \mathrm{~h}$. The membranes were then washed extensively for $1 \mathrm{~h}$ with PBS containing $0 \cdot 1 \%$ Tween 20 and the immune complexes were stained using a horseradish peroxidase technique (Weber et al. 1994).

\section{Two-dimensional (2D)-WLB analysis of human IGFBPs}

IGFBPs were further characterized in conditioned cell culture medium from stimulation experiments by 2D-WLB as previously described (Weber et al. 1999). In brief, $2 \mathrm{ml}$ medium was concentrated 50 -fold in a Millipore ultrafree filter unit, mixed with an equal volume of IPG buffer ( $8 \mathrm{M}$ urea and $0 \cdot 2 \%$ pharmalyte 3-10; Pharmacia) and incubated for $1 \mathrm{~h}$ at room temperature. The samples were then loaded on precast immobilized $\mathrm{pH}$ gradient (IPG) gels $(0.5 \times 3 \times 110 \mathrm{~mm}$; Immobiline DryStrip; Pharmacia, Freiburg, Germany). Isoelectric focusing was carried out at $20^{\circ} \mathrm{C}$ for $0.5 \mathrm{~h}$ with $200 \mathrm{~V}$, followed by $6 \mathrm{~h}$ with $3000 \mathrm{~V}$ in a cooled horizontal electrophoresis unit (Multiphor II; Pharmacia). For separation in the second dimension (SDSPAGE electrophoresis), the IPG strips were equilibrated for $15 \mathrm{~min}$ in $50 \mathrm{mM}$ Tris- $\mathrm{HCl}(\mathrm{pH} 8 \cdot 8), 6 \mathrm{M}$ urea, $30 \%$ glycerol, $2 \%$ SDS and a trace of bromphenol blue and placed on a horizontal SDS-PAGE gel (12\%). After protein transfer ( $45 \mathrm{~min}$ at $200 \mathrm{~V}$ ), the IPG strips were removed, and non-reducing SDS-PAGE electrophoresis was continued at $600 \mathrm{~V}$. After 2D gel electrophoresis, the IGFBPs were identified by autoradiography following overnight incubation of the filters with ${ }^{125}$ I-labeled IGF-II as described.

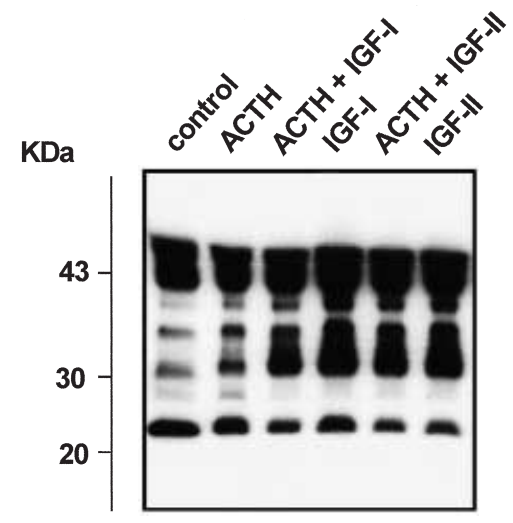

Figure 1 WLB of IGFBPs secreted by human adrenocortical cells. Cells were incubated with serum-free medium alone (control), ACTH (1 nM) and/or IGFs (6.5 nM) for $48 \mathrm{~h}$. Conditioned medium was concentrated, separated by SDS-PAGE under non-reducing conditions, transferred to PVDF membranes, incubated with

${ }^{125}$ I-labeled IGF-I and autoradiographed. Data are representative of a single experiment performed independently seven times.

\section{Statistics}

Data are depicted as the means \pm S.E.M., and differences between specific treatment group and unstimulated control were assessed by non-paired $t$-testing.

\section{Results}

Identification of IGFBPs secreted by adult human adrenocortical cells

In order to identify the IGFBPs synthesized by adult human adrenocortical cells, WLB of adrenocortical cellconditioned medium was performed with $\left[{ }^{125} \mathrm{I}\right] \mathrm{IGF}-\mathrm{I}$ or ${ }^{125}$ I]IGF-II. As shown in Fig. 1, the medium of untreated control cells contained at least five specific bands, with a major doublet of 39-44 kDa, and additional bands at 36, 34, 31/32, 29 and $24 \mathrm{kDa}$. According to their estimated molecular weight, the $39-44 \mathrm{kDa}$ doublet corresponds to different glycosylation variants of IGFBP-3, the $34 \mathrm{kDa}$ band to IGFBP-2, and the $24 \mathrm{kDa}$ band represents IGFBP-4. The molecular weight of the 29-32 kDa bands, however, would be compatible with IGFBP-1, glycosylated IGFBP-4, IGFBP-5 and IGFBP-6. A similar binding pattern was observed when cytosol extracts of human adrenocortical cells were analyzed by WLB (data not shown). When conditioned medium was subjected to enzymatic deglycosylation prior to WLB, the $39-44 \mathrm{kDa}$ doublet was deglycosylated to a single band of approximately $36 \mathrm{kDa}$ as expected for IGFBP-3, while the doublet at 31/32 kDa remained unchanged. Furthermore, the WLB binding pattern was the same when $\left.{ }^{125} \mathrm{I}\right] \mathrm{IGF}-\mathrm{I}$ or $\left[{ }^{125} \mathrm{I}\right] \mathrm{IGF}-\mathrm{II}$ were employed as radioligands (data not shown). This makes it very unlikely that the $29-32 \mathrm{kDa}$ 


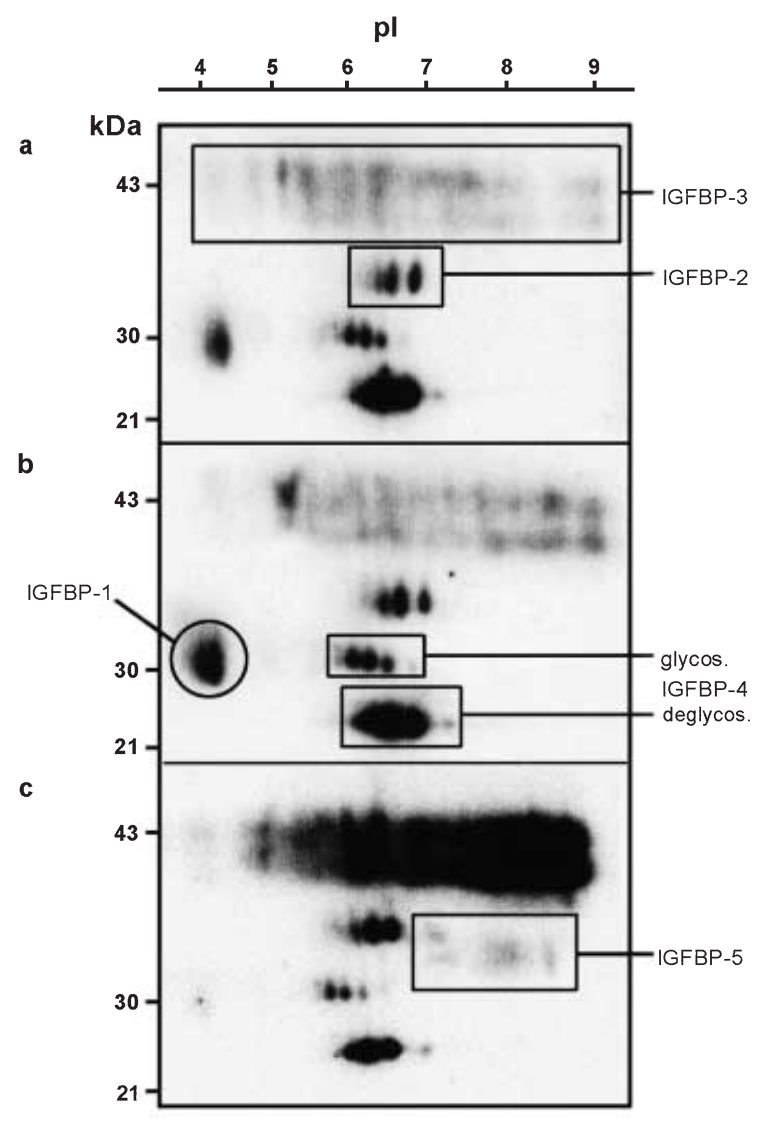

Figure 2 2D-WLB analysis of IGFBPs secreted by human adrenocortical cells. Cells were incubated with serum-free medium alone (control) (a), ACTH (1 nM) (b) or IGF-I (6.5 nM) (c) for $48 \mathrm{~h}$. Conditioned medium was concentrated and the samples were loaded on precast immobilized pH gradient gels (IPG strips) for isoelectric focusing. For separation in the second dimension (SDS-PAGE electrophoresis), the IPG strips were then transferred to a polyacrylamide gel (12\%) and a non-reducing SDS-PAGE electrophoresis followed by a conventional WLB with ${ }^{125}$ I-labeled IGF-II was performed. Data are representative of three independently performed experiments.

bands represent IGFBP-6, since human IGFBP-6 exhibits a 10- to 100-fold higher affinity for IGF-II than for IGF-I (Rechler 1995).

In order to identify the different IGFBPs with a molecular weight between 29 and $32 \mathrm{kDa}$ and to further characterize possible post-translational modifications of the binding proteins, we subjected conditioned medium of adult human adrenocortical cells to 2D-WLB analysis (Fig. 2). This method has previously been described as a powerful tool to identify all six human high-affinity IGFBPs and their isoforms in complex biological fluids (Weber et al. 1999). In accordance with the conventional WLB, IGFBP-3 was the most prominent binding protein, represented by two broad bands of specific spots with an apparent molecular mass of $41-45 \mathrm{kDa}$ and a $\mathrm{pI}$ ranging

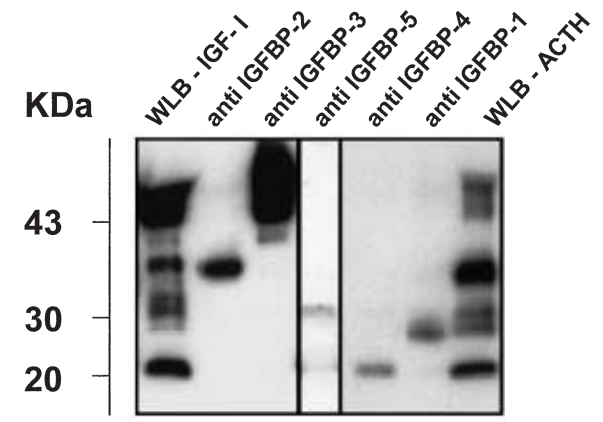

Figure 3 Identification of IGFBPs secreted by adult human adrenocortical cells. Cells were incubated with serum-free medium and ACTH ( $1 \mathrm{nM})$ for $48 \mathrm{~h}$. Conditioned medium was immunoprecipitated with anti IGFBP-1 (lane 6), anti IGFBP-2 (lane 2), anti IGFBP-3 (lane 3), anti IGFBP-4 (lane 5) and anti IGFBP-5 (lane 4), separated by SDS-PAGE under non-reducing conditions, transferred to PVDF membranes, incubated with ${ }^{125}$ I-labeled IGF-I and autoradiographed. Lanes 1 and 7 represent IGF-I (6.5 nM)and ACTH-treated ( $1 \mathrm{nM})$ controls. Data are representative of three independently performed experiments.

from $4 \cdot 0$ to $9 \cdot 2$ (Fig. 2). At $34 \mathrm{kDa}$, IGFBP-2 was detectable, consisting of four major spots with $\mathrm{pI}$ values of $6-7 \cdot 1$. The smallest bands with a molecular weight of $24 \mathrm{kDa}$ represent deglycosylated IGFBP-4 with $\mathrm{pI}$ values of $6 \cdot 2,6 \cdot 5,6 \cdot 8$ and $7 \cdot 2$. When the binding proteins with a molecular weight between 29 and $32 \mathrm{kDa}$ were analyzed, at least four isoforms of glycosylated IGFBP-4 with a molecular weight of $29-30 \mathrm{kDa}$ and $\mathrm{pI}$ values of $5 \cdot 9,6 \cdot 1,6 \cdot 4$ and $6 \cdot 6$ could be detected. In addition, IGFBP-1 is seen as a single spot at $30 \mathrm{kDa}$ with a $\mathrm{pI}$ of $4 \cdot 2$. Due to its low concentration, IGFBP-5 was visible only after treatment of the cells with IGF-I, presenting as a faint series of doublet spots with a molecular mass of 31/32 and pI values between 6.6 and 8.8 (Fig. 2c). IGFBP-6, which in human serum is found as a series of spots with a $\mathrm{pI}$ of $4 \cdot 8-5 \cdot 8$ and a molecular mass of $29-31 \mathrm{kDa}$, could not be detected in conditioned medium from adult human adrenocortical cells.

In order to further confirm the identity of the IGFBPs secreted by adrenocortical cells, conditioned medium was subjected to immunoprecipitation using specific antisera against human IGFBPs prior to conventional WLB (Fig. 3). Antiserum against human IGFBP-3 precipitated the $39-42 \mathrm{kDa}$ doublet as well as a faint band at $36 \mathrm{kDa}$, representing the deglycosylated form of IGFBP-3. Antiserum against human IGFBP-2 precipitated a single band at $34 \mathrm{kDa}$, while antiserum against human IGFBP-5 precipitated a faint double band at $31-32 \mathrm{kDa}$. The $29 \mathrm{kDa}$ band was immunoprecipitated with antiserum against human IGFBP-1, and the $24 \mathrm{kDa}$ band with antiserum against human IGFBP-4. No band was detected after immunoprecipitation or immunoblotting of conditioned medium with a polyclonal antibody against IGFBP-6, which detected even small amounts of 
IGFBP-6 in human cerebrospinal fluid as a positive control, thus excluding the presence of significant amounts of IGFBP-6. In order to further confirm these results and to detect the presence of IGFBP fragments which do not bind IGF ligands, Western immunoblots of conditioned medium were performed using specific antibodies against human IGFBP-1 to -6 . In accordance with the results of the WLB analysis after immunoprecipitation the same specific bands of IGFBP-1 to -5 were detected in conditioned medium from adrenocortical cells by Western immunoblotting. Interestingly, no IGFBP-3 fragments could be detected in the supernatant of adult human adrenocortical cells, although large amounts of a $30 \mathrm{kDa}$ IGFBP-3 fragment were found in human serum samples (data not shown).

\section{Regulation of IGFBP secretion}

When adult human adrenocortical cells were treated with ACTH or IGFs, the intensity of all bands was markedly, but differentially increased (Fig. 1). The noted increase in IGFBP abundance was not due to growth-promoting effects, since the ligands did not elicit any changes in cell number under the conditions used. Semi-quantitative analysis of the IGFBP bands of eight independent experiments by gamma counting indicated that, in unstimulated cells, IGFBP-3 accounted for almost half of the detected IGFBP activity $(46 \cdot 5 \pm 4 \cdot 6 \%)$, followed by IGFBP-4 $(20 \cdot 4 \pm 3 \cdot 5 \%), \quad$ IGFBP-5 $\quad(15 \cdot 6 \pm 2 \cdot 3 \%), \quad$ IGFBP-2 $(11 \cdot 5 \pm 4 \cdot 0 \%)$ and IGFBP-1 $(6 \cdot 0 \pm 1 \cdot 5 \%)$. After treatment of the cells with ACTH (1 nM for $48 \mathrm{~h}$ ), the abundance of IGFBP-1 was upregulated $2 \cdot 6$-fold as compared with the untreated control of the same experiment $(n=8, P<0 \cdot 05)$, while IGFBP-3 was slightly induced $(1 \cdot 3$-fold, not significant). The small ACTH-induced increase in IGFBP-4 (1.3-fold) was statistically not significant and IGFBP-2 as well as IGFBP-5 remained unchanged (Fig. 4a). In contrast to ACTH, the incubation of adrenocortical cells with IGF-I and IGF-II $(6 \cdot 5 \mathrm{nM})$ predominantly induced the abundance of IGFBP-5 (2-fold by IGF-I and 1.6-fold by IGF-II, $P<0 \cdot 05$ ), and IGFBP-3 (2-fold by IGF-I, $1 \cdot 7$-fold by IGF-II, $P<0 \cdot 05$ ), while the moderate increase in IGFBP-2 was not significant. The abundance of IGFBP-4 was decreased by $40 \%$ in the presence of IGF-II (not significant), and IGFBP-1 remained unchanged. Although not statistically significant, IGF-I induced IGFBP-3 and -5 abundance more potently than equimolar concentrations of IGF-II, as opposed to the stronger steroidogenic potency of IGF-II in these cells (Fig. 4b). In contrast to the differential induction of IGFBP synthesis by ACTH and IGFs, no significant difference in the amount of total protein secretion was found after stimulation with IGFs and ACTH (IGF-I, $15.27 \pm 0.67 \mu \mathrm{g} / \mathrm{ml}$; IGF-II, $14.84 \pm 0.65 \mu \mathrm{g} / \mathrm{ml} ; \quad$ ACTH, $14 \cdot 26 \pm 0.55 \mu \mathrm{g} / \mathrm{ml})$. In order to evaluate the effects of corticosteroids on IGFBP secretion, the incubation experiments were performed in
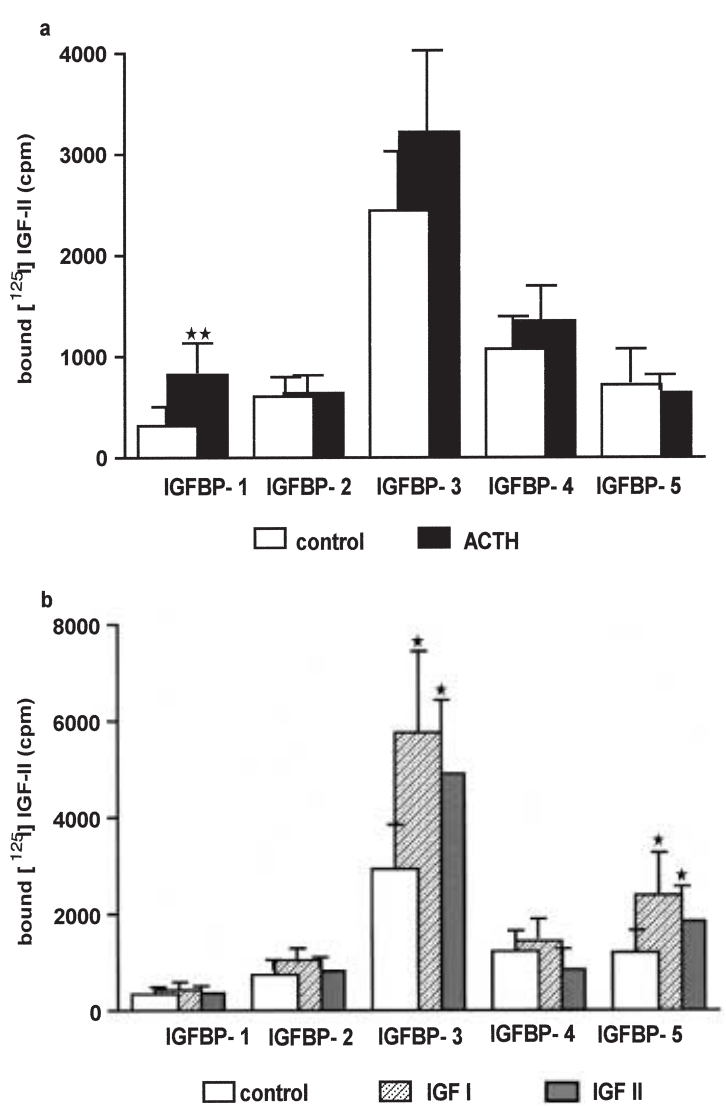

Figure 4 Effect of ACTH (a) and IGFs (b) on IGFBP abundance in conditioned medium of adult human adrenocortical cells. Cells were incubated in multiwell plates in the presence of ACTH $(1 \mathrm{nM})$ and IGF-I or IGF-II $(6 \cdot 5 \mathrm{nM})$ for $48 \mathrm{~h}$. Conditioned medium was concentrated, separated by SDS-PAGE under non-reducing conditions, transferred to PVDF membrane, incubated with ${ }^{125}$ I-labeled IGF-I, autoradiographed and quantified by gamma counting of the specific bands. Results are means \pm S.E.M. of eight independently performed incubation experiments. ${ }^{*} P<0 \cdot 05$ vs untreated control, ${ }^{* *} P<0 \cdot 01$ vs untreated control.

the presence or absence of $0 \cdot 1 \mathrm{mM}$ dexamethasone. While the steroidogenic effect of ACTH and IGFs was blunted by dexamethasone, the pattern of IGFBPs and their regulation by $\mathrm{ACTH}$ and IGFs remained unchanged, excluding an indirect effect of ACTH or IGFs on IGFBP abundance via accumulating corticosteroids in the incubation medium. When conditioned medium of adrenocortical cells was subjected to $2 \mathrm{D}-\mathrm{WLB}$, similar results with an induction of IGFBP-1 by ACTH (Fig. 2b) and an increase in the amount of IGFBP-3 and IGFBP-5 (Fig. 2c) after treatment with IGFs was found. Interestingly, a shift to the basic isoforms of IGFBP-3 (pI range 7-9) was found after treatment with IGFs (Fig. 2a and c). In contrast, the amount of IGFBP-2 and of glycosylated and unglycosylated IGFBP-4 remained unchanged after treatment with IGFs or ACTH (Fig. 2). 

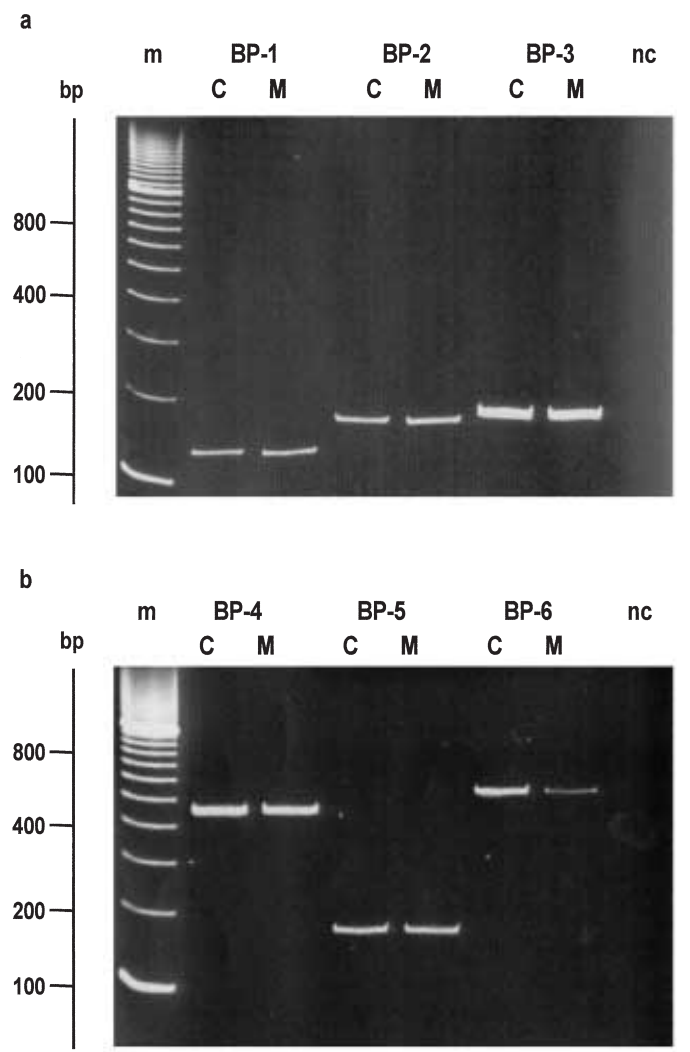

Figure 5 Identification of the mRNA for IGFBP-1 to -6 expressed by adult human adrenocortical and adrenomedullary cells. The human adrenal cortex was separated from the adrenomedullary tissue under a dissecting microscope. After RNA extraction of a $50 \mathrm{mg}$ tissue sample, the mRNA was reverse transcribed and CDNA probes were amplified using PCR with specific primers for IGFBP-1 to -6. (a) The mRNA content of human adrenal cortex (C) and adrenal medulla (M) for IGFBP-1, -2 and -3 . (b) The mRNA content of human adrenal cortex $(\mathrm{C})$ and adrenal medulla $(\mathrm{M})$ for IGFBP-4, -5 and $-6 . \mathrm{m}=100$ bp ladder molecular marker, $\mathrm{nc}=$ negative control. Data are representative of a single experiment performed independently eight times.

\section{IGFBP $m R N A$ expression in the human adult adrenal gland}

Using RT-PCR all six high-affinity binding proteins were found in normal adult human adrenal glands (Fig. 5). No significant difference in the amplification of the binding proteins was observed between adrenocortical and adrenomedullary tissue. In order to further evaluate if the observed increase in IGFBP content of adrenocortical cells after treatment with ACTH or IGFs was paralleled by an increase in mRNA levels, a semiquantitative RT-PCR was performed with adrenocortical cells (Fig. 6). After treatment of the cells with ACTH (1 nM for $48 \mathrm{~h}$ ), the abundance of IGFBP-1 mRNA was upregulated $2 \cdot 3 \pm 0 \cdot 2$-fold as compared with the untreated control group $(n=4, \quad P<0 \cdot 05)$, while IGFBP-3 mRNA was induced only slightly $(1 \cdot 5 \pm 0 \cdot 3$-fold, not significant $)$ and the IGFBP-5 mRNA remained unchanged (Fig. 6a). In
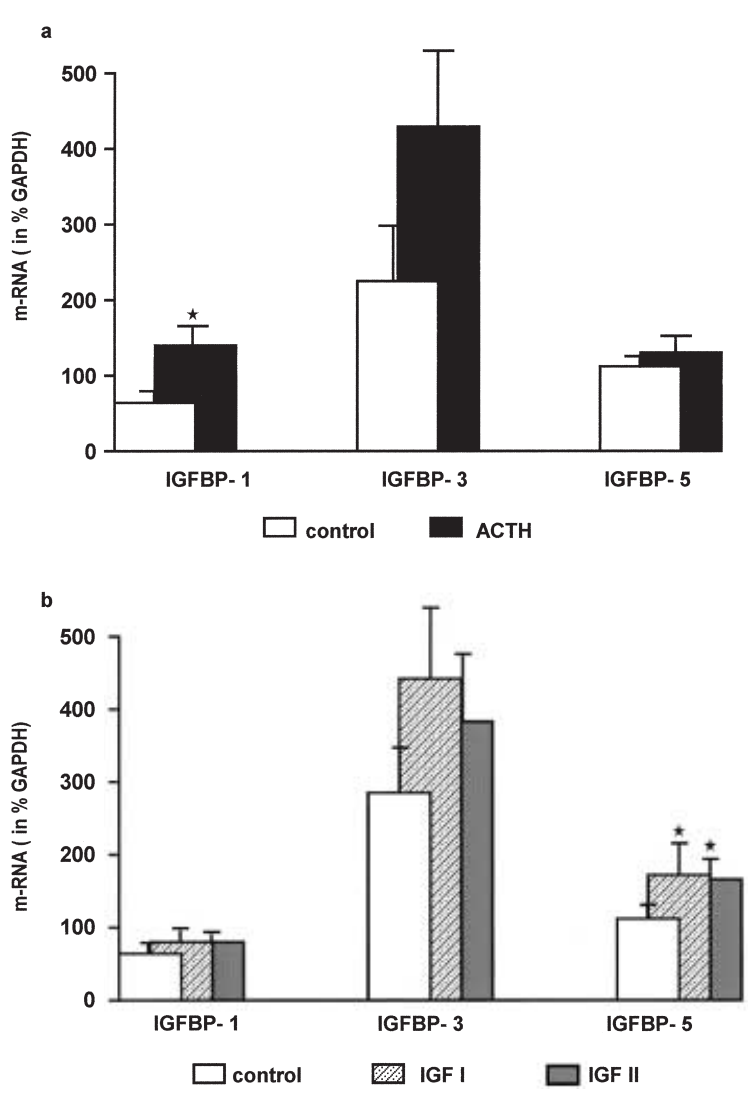

Figure 6 Effect of ACTH (a) and IGFs (b) on mRNA abundance of IGFBP-1, IGFBP-3 and IGFBP-5 of adult human adrenocortical cells. Cells were incubated in multiwell plates in the presence of ACTH (1 nM), IGF-I or IGF-II $(6.5 \mathrm{nM})$ for $48 \mathrm{~h}$. After RNA extraction from adrenocortical cells, the mRNA was reverse transcribed and cDNA probes were amplified using PCR with specific primers for IGFBP-1, -3 and -5. GAPDH was co-amplified as an internal control and results are expressed as relative levels of specific mRNA normalized for GAPDH. Results are means \pm S.E.M. of four independently performed incubation experiments. ${ }^{*} P<0 \cdot 05$ vs untreated control.

contrast to ACTH, IGF-I or IGF-II $(6.5 \mathrm{nM})$ predominantly induced the abundance of the mRNA for IGFBP-5 $(1 \cdot 5 \pm 0 \cdot 2$-fold by IGF-I and $1 \cdot 5 \pm 0 \cdot 3$-fold by IGF-II, $P<0 \cdot 05)$, and IGFBP-3 (1.6 $\pm 0 \cdot 3$-fold by IGF-I, $1 \cdot 3 \pm 0 \cdot 3$-fold by IGF-II, not significant), while IGFBP-1 remained unchanged. Although not statistically significant, IGF-I induced IGFBP-3 and -5 abundance more potently than equimolar concentrations of IGF-II, as opposed to the stronger steroidogenic potency of IGF-II in these cells (Fig. 6b).

\section{Discussion}

In this study we identified and characterized IGFBP synthesis in the adult human adrenal gland and evaluated 
their regulation by ACTH and IGFs, both at the protein and the mRNA level. As assayed by WLB of conditioned medium, human adrenocortical cells secrete at least five different molecular forms of IGFBPs which are regulated differentially by ACTH and IGFs. According to their electrophoretic size and glycosylation status, the major $39 / 44 \mathrm{kDa}$ doublet corresponds to different glycosylation variants of IGFBP-3, the $34 \mathrm{kDa}$ band to IGFBP-2 and the smallest $24 \mathrm{kDa}$ band to deglycosylated IGFBP-4. As expected, their identity was confirmed by $2 \mathrm{D}-\mathrm{WLB}$ and immunological methods. Furthermore, the $29 \mathrm{kDa}$ band and the faint doublet at $31 / 32 \mathrm{kDa}$, which exhibited a similar affinity for both IGFs, and which could not be $\mathrm{N}$-deglycosylated, could be identified as IGFBP-1 and IGFBP-5 respectively by $2 \mathrm{D}-\mathrm{WLB}$, immunoprecipitation and Western immunoblotting. In contrast, no significant secretion of IGFBP-6 by human adrenocortical cells could be detected. Quantification of the specific bands by gamma counting revealed that IGFBP-3 accounts for more than half of the detected IGFBP activity, followed by IGFBP-1 with 20\%, and IGFBP-2 as well as IGFBP-4 with approximately $10 \%$ each. However, one has to keep in mind that the activity of the specific bands in WLBs is influenced by the affinity of the IGF radioligand to the various IGFBPs, and therefore does not necessarily reflect the absolute amount of IGFBPs present in a given sample. Nevertheless, WLB is a very sensitive and specific method for the detection of small amounts of IGFBPs in complex biological fluids. By RT-PCR, we were able to demonstrate the expression of all six high-affinity binding proteins both in adrenocortical and in adrenomedullary tissue from adult human adrenal glands. Treatment of adult human adrenocortical cells with ACTH predominantly stimulated the abundance of IGFBP-1, and to a lesser extent that of IGFBP-3, while IGF-I and IGF-II relatively selectively induced the accumulation of IGFBP-3 and IGFBP-5 in the medium. Since IGFBP-1 and glycosylated IGFBP-4 migrate in the conventional WLB at approximately the same size of $29 \mathrm{kDa}$, a small contamination of the IGFBP-1 counts by glycosylated forms of IGFBP-4 cannot be completely excluded. However, this seems to be of minor importance, since enzymatic deglycosylation does not significantly alter the activity of the $29 \mathrm{kDa}$ band and since the amount of glycosylated IGFBP-4 remained unchanged after treatment with ACTH or IGFs as analyzed by 2D-WLB. In parallel to the induction of IGFBPs in the medium, the mRNA concentration of IGFBP-1, IGFBP-3 and IGFBP-5 was increased in adrenocortical cells after treatment with ACTH and IGFs respectively, as assessed by semiquantitative RTPCR. In analogy to the findings in human adrenocortical cells, a similar induction of IGFBP-1 by ACTH and of IGFBP-3 by IGFs has been found in bovine adrenocortical cells (Fottner et al. 1999).

The control of IGFBP abundance is complex and includes changes in IGFBP transcription, proteolytic clearance, receptor or ligand-binding activity and cellular localization (Rechler 1993, Jones \& Clemmons 1995). In fetal adrenocortical cells, considerable differences between IGFBP concentration and mRNA levels have been observed. This points to a significant regulation of IGFBP synthesis at the pre- and post-translational level (Ilvesmäki et al. 1993). A similar mechanism has already been shown in human fibroblasts, where IGFs induce the abundance of IGFBP-3 and -5 and decrease IGFBP-4 by posttranslational mechanisms, involving activation or inhibition of specific IGFBP proteases (Bale \& Conover 1992, Camacho-Hubner et al. 1992, Conover et al. 1995). In adult human adrenocortical cells, however, induction of IGFBP secretion by ACTH and IGFs was paralleled by an increase in the mRNA concentration of the corresponding binding protein, indicating a regulation at the transcriptional level. Furthermore, the fact that IGF-I was slightly more potent than IGF-II in stimulating adrenal IGFBP expression and secretion suggests that this effect is mediated through interaction with the IGF-I receptor.

Although the regulation of IGFBP production by IGFs is highly cell and species specific, a stimulatory effect of IGFs on IGFBP-3 has been reported in a large variety of cell systems, which accords well with our findings in adrenocortical cells (Bale \& Conover 1992, CamachoHubner et al. 1992, Martin \& Baxter 1992, Rechler 1993, Conover et al. 1994, 1995, Jones \& Clemmons 1995). Furthermore, IGFBP-1 synthesis is induced by cAMP in human hepatoma cells, and a cAMP-dependent element has been identified in the IGFBP-1 promoter (Lee et al. 1993, Suwanichkul et al. 1993). This is consistent with our finding of a relative selective induction of adrenocortical IGFBP-1 by ACTH, which is a potent inductor of cAMP. The stimulation of IGFBP-1 by ACTH seems to be specific for the adult adrenal gland, since in fetal human adrenocortical cells no regulation of IGFBPs by ACTH has been found (Ilvesmäki et al. 1992).

The physiological significance of IGFBP secretion by adrenocortical cells is unknown. However, since IGFs are potent stimulators of adrenocortical cell function and IGFBPs are modulators of the cellular responsiveness to IGFs, changes in the cellular expression of IGFBPs may represent an important level of control in adrenocortical cell physiology. This is supported by our recent finding of an increased steroidogenic effect of truncated IGF variants with reduced affinity for IGFBPs (Fottner et al. 1999). The fact that $\left[\mathrm{des}^{1-3}\right]$ IGF-I, which exhibits decreased binding to IGFBPs, was significantly stronger than native IGF-I in stimulating ACTH-induced cortisol secretion from adult human and bovine adrenocortical cells, indicates that the stronger steroidogenic effect of IGF-II might be explained by a modulatory effect of locally produced IGFBPs. Since the poor binding of $\left[\mathrm{des}^{1-3}\right]$ IGF-I to IGFBPs correlates well with its increased bioactivity, a preferential interaction of IGF-I with an inhibitory IGFBP could explain the different steroidogenic potency of IGF-I and IGF-II in 
adult human adrenocortical cells. This mechanism has been postulated for various other cell systems where increased bioactivities of truncated IGF-I in comparison with native IGF-I have been found (Francis et al. 1993, Rechler 1995). A possible candidate for this modulating role in adrenocortical cells is IGFBP-1, which is specifically regulated by ACTH. Depending on its phosphorylation status, IGFBP-1 is able to inhibit IGF action in vitro (Jones et al. 1991), and phosphorylated IGFBP-1 has been reported to exhibit a slightly stronger affinity for IGF-I as compared with IGF-II (Westwood et al. 1997). However, IGFBPs are able to modulate IGF action through a variety of mechanisms (Jones \& Clemmons 1995), and further investigations will have to show through which binding protein and by which mechanism the modulatory effect of IGFBPs on adrenocortical steroidogenesis is exerted.

The fact that the selective induction of IGFBP-1 by ACTH as well as the predominant induction of IGFBP-3 by IGFs are conserved between the bovine and human adrenocortical cell culture system (Weber et al. 1995, Fottner et al. 1999), adds further support to the hypothesis that IGFBPs play a significant role in the regulation of adrenocortical cell function. In addition to their differentiating potency, IGFBPs might be important modulators of adrenocortical cell growth. This is supported by recently published studies, which show that overexpression of IGFBP-2 in a adrenocortical carcinoma cell line is associated with a highly malignant phenotype (Hoeflich et al. 2000), and that IGFBP-2 is the main binding protein secreted by malignant adrenocortical cells (Boulle et al. 1998). In normal adrenocortical cells, however, IGFBP-2 accounts for only $12 \%$ of the IGFBP activity, and its abundance is not regulated by ACTH or IGFs. This makes it unlikely that the overexpression of IGFBP-2 in adrenocortical carcinomas is merely an epiphenomenon and suggests that IGFBP-2 plays an important role in the regulation of adrenocortical cell proliferation. However, further studies will have to evaluate the pathophysiological significance of the observed overexpression of IGF-I receptors, IGF-II ligand and IGFBP-2 in these highly malignant tumors (Voutilainen \& Miller 1987, Ilvesmäki et al. 1993, Gicquel et al. 1994, Boulle et al. 1998).

In summary, the present study shows that all six high-affinity IGFBPs are expressed in the adult human adrenal gland. Furthermore, adult human adrenocortical cells secrete IGFBP-1 to IGFBP-5 and their synthesis is regulated differentially by ACTH and IGFs, presumably at a transcriptional level. Therefore, adult human adrenocortical cells provide a useful cell culture system in which the role of IGFBPs in modulating IGF signaling through the IGF-I receptor can be evaluated.

\section{Acknowledgements}

The authors are grateful to Gerald Spöttl and Daniela Köndgen for excellent technical assistance. This work is part of the doctoral thesis of $\mathrm{C} \mathrm{F}$ at the Faculty of Medicine, University of Munich, Germany. The work was supported by DFG Grant WE 1356/4-2 (to M M W).

\section{References}

Bale LK \& Conover CA 1992 Regulation of insulin-like growth factor binding protein-3 messenger ribonucleic acid expression by insulin-like growth factor I. Endocrinology 131 608-614.

Boulle N, Logié A, Gicquel C, Perin L \& Le Bouc Y 1998 Increased levels of insulin-like growth factor II (IGF-II) and IGF-binding protein-2 are associated with malignancy in sporadic adrenocortical tumors. Journal of Clinical Endocrinology and Metabolism 83 1713-1720.

Camacho-Hubner C, Busby WH, McCusker RH, Wright G \& Clemmons DR 1992 Identification of the forms of insulin-like growth factor-binding proteins produced by human fibroblasts and the mechanisms that regulate their secretion. Journal of Biological Chemistry 267 11949-11956.

Chomczynski P \& Sacchi N 1987 Single step method of RNA isolation by acid guadinium thiocyanate-phenol-chloroform extraction. Annals of Biochemistry 162 156-159.

Clemmons DR 1990 Insulin like growth factor binding proteins. Trends in Endocrinology and Metabolism 1 412-417.

Conover CA, Clarkson JT \& Bale LK 1994 Insulin-like growth factor-II enhancement of human fibroblast growth via a nonreceptor-mediated mechanism. Endocrinology 135 76-82.

Conover CA, Clarkson JT \& Bale LK 1995 Effect of glucocorticoid on insulin-like growth factor (IGF) regulation of IGF-binding protein expression in fibroblasts. Endocrinology 136 1403-1410.

Elmlinger MW, Wimmer K, Biemer E, Dannecker L, Blum WF, Ranke MB \& Dannecker GE 1996 Insulin-like growth factor binding protein-2 (IGFBP-2) is differentially expressed in leukemic T- and B-cell lines. Growth Regulation 6 152-157.

Elmlinger MW, Sanatani MS, Bell M, Dannecker GE \& Ranke MB 1998 Elevated insulin-like growth factor (IGF) binding protein (IGFBP)-2 and IGFBP-4 expression of leukemic T-cells is affected by autocrine/paracrine IGF-II action but not by IGF type I receptor expression. European Journal of Endocrinology 138 337-343.

Fottner C, Engelhardt D \& Weber MM 1998 Regulation of steroidogenesis by insulin-like growth factors (IGFs) in adult human adrenocortical cells: IGF-I, and more potently IGF-II, preferentially enhance androgen biosynthesis through interaction with the IGF-I receptor and IGF-binding proteins. Journal of Endocrinology 158 409-417.

Fottner C, Engelhardt D \& Weber MM 1999 Characterization of insulin-like growth factor binding proteins (IGFBPs) secreted by bovine adrenocortical cells in primary culture: regulation by insulin-like growth factors (IGFs) and adrenocorticotropin (ACTH). Hormone and Metabolic Research 31 203-208.

Francis GL, Alpin SE, Milner SJ, McNeil KA, Ballard JF \& Wallace JC 1993 Insulin-like growth factor (IGF)-II binding to IGF-binding proteins and IGF receptors is modified by deletion of the

N-terminal hexapeptide or substitution of arginine for glutamate-6 in IGF-II. Journal of Biochemistry 293 713-719.

Gicquel C, Bertagna X, Schneid H, Francillard-Leblond M, Luton JP, Girard F \& Le Bouc Y 1994 Rearrangements at the 11p15 locus and over expression of insulin-like growth factor-II gene in sporadic adrenocortical tumors. Journal of Clinical Endocrinology and Metabolism 78 1444-1453.

Hoeflich A, Fettscher O, Lahm H, Kolb HJ, Engelhardt D, Wolf E \& Weber MM 2000 Overexpression of insulin-like growth factor binding protein 2 results in increased tumorigenic potential in $\mathrm{Y}-1$ adrenocortical tumor cells. Cancer Research 60 834-838.

Ilvesmäki V, Blum WF \& Voutilainen R 1992 Insulin-like growth factor-II in human fetal adrenals: regulation by ACTH, protein kinase C and growth factors. Journal of Endocrinology 137 533-542. 
Ilvesmäki V, Kahri AI, Miettinen PJ \& Voutilainen R 1993 Insulin-like growth factors (IGFs) and their receptors in adrenal tumors: high IGF-II expression in functional adrenocortical carcinomas. Journal of Clinical Endocrinology and Metabolism 77 $852-858$.

Jones JI \& Clemmons DR 1995 Insulin-like growth factors and their binding proteins: biological actions. Endocrine Reviews 16 3-34.

Jones JI, D’Ercole AJ, Camacho-Hubner C \& Clemmons DR 1991 Phosphorylation of insulin-like growth factor (IGF)-binding protein 1 in cell culture and in vivo: effects on affinity for IGF-1. PNAS $\mathbf{1 8}$ 7481-7485.

Kristiansen SB, Endoh A, Casson PR, Buster JE \& Hornsby PJ 1997 Induction of steroidogenic enzyme genes by insulin and IGF-I in cultured adult human adrenocortical cells. Steroids 62 258-265.

L'Allemand D, Penhoat A, Lebrethon M-C, Ardèvol R, Baehr V, Oelkers W \& Saez J M 1996 Insulin-like growth factors enhance steroidogenic enzyme and corticotropin receptor messenger ribonucleic acid levels and corticotropin steroidogenic responsiveness in cultured human adrenocortical cells. Journal of Clinical Endocrinology and Metabolism 81 3892-3897.

Lee PDK, Conover CA \& Powell DR 1993 Regulation and function of insulin-like growth factor-binding protein-1. Proceedings of Social Experimental and Biological Medicine 204 4-29.

LeRoith D, Adamo M, Werner H \& Roberts CT 1991 Insulin-like growth factors and their receptors as growth regulators in normal physiology and pathological state. Trends in Endocrinology and Metabolism 2 134-139.

Martin JL \& Baxter RC 1992 Insulin-like growth factor binding protein-3: biochemistry and physiology. Growth Regulation 2 88-99.

Pham-Huu-Trung MT, Villette JM, Bogyo A, Duclos JM, Fiet J \& Binoux M 1991 Effects of insulin-like growth factor-I (IGF-I) on enzymatic activity in human adrenocortical cells. Interactions with ACTH. Journal of Steroid Biochemistry and Molecular Biology 39 903-909.

Rechler MM 1993 Insulin-like growth factor binding proteins. Vitamins and Hormones 47 1-114.

Rechler MM 1995 Non-receptor-binding proteins for insulin-like growth factors and other cytokines: modulators of peptide action. In Molecular Endocrinology. Basic Concepts and Clinical Correlations, vol. 1, pp 155-180. Ed. BD Weintraub. New York: Raven Press Ltd.

Rechler MM \& Nissley SP 1990 Insulin-like growth factors. In Handbook of Experimental Pharmacology, pp 263-367. Eds MS Sporn \& AB Roberts. Heidelberg, New York: Springer Verlag.

Roth RA 1988 Structure of the receptor for insulin-like growth factor II: the puzzle amplified. Science 239 1269-1271.

Suwanichkul A, DePaolis LA, Lee PDK \& Powell DR 1993 Identification of a promoter element which participates in
cAMP-stimulated expression of human insulin-like growth factorbinding protein-1. Journal of Biological Chemistry 268 9730-9736.

Underwood LE, D’Ercole AJ, Clemmons DR \& Van Wyk JJ 1986 Paracrine functions of somatomedins. Clinical Endocrinology and Metabolism 15 59-77.

Voutilainen R \& Miller WL 1987 Coordinate tropic hormone regulation of mRNAs for insulin-like growth factor II and the cholesterol side-chain-cleavage enzyyme, P450 ssc, in human steroidogenic tissues. PNAS 84 1590-1594.

Weber MM, Kiess W, Beikler T, Simmler P, Reichel M, Adelmann B, Kessler U \& Engelhardt D 1994 Identification and characterization of insulin-like growth factor I (IGF-I) and IGF-II/mannose-6-phosphate (IGF-II/M6P) receptors in bovine adrenal cells. European Journal of Endocrinology 130 265-270.

Weber MM, Simmler P, Fottner C \& Engelhardt D 1995 Insulin-like growth factor II (IGF-II) is more potent than IGF-I in stimulating cortisol secretion from cultured bovine adrenocortical cells: interaction with the IGF-I receptor and IGF-binding proteins. Endocrinology 136 3714-3720.

Weber MM, Auernhammer CJ, Kiess W \& Engelhardt D 1997 Insulin-like growth factor receptors in normal and tumorous adult human adrenocortical glands. European Journal of Endocrinology 136 296-303.

Weber M, Fottner C \& Engelhardt D 1998 Adrenocortical and adrenomedullary cells. Endocrine cell culture. In Handbooks in Practical Cell Biology, pp 74-93. Ed. S Bidey. Cambridge: Cambridge University Press.

Weber MM, Spöttl G, Gössl C \& Engelhardt D 1999 Characterization of human insulin-like growth factor binding proteins by two dimensional polyacrylamide gel electrophoresis and western ligand blot analysis. Journal of Clinical Endocrinology and Metabolism 84 1679-1684.

Westwood M, Gibson J M \& White A 1997 Purification and characterization of the insulin-like growth factor-binding protein-1 phosphoform found in normal plasma. Endocrinology 138 1130-1136.

Zapf J, Schmid C, Guler HP, Waldvogel M, Hauri C, Futo E, Hossenlopp P, Binoux M \& Froesch ER 1990 Regulation of binding proteins for insulin-like growth factors (IGF) in humans: increased expression of IGF binding protein 2 during IGF-I treatment of healthy adults in patients with extrapancreatic tumor hypoglycemia. Journal of Clinical Investigation 86 952-961.

Received 10 August 2000

Accepted 16 November 2000 